\title{
AN OVERVIEW OF THE ORGANIC INDUSTRY IN NEW ZEALAND
}

\author{
G. CRAWSHAW \\ President, Organic Kiwifruit Growers Assoc. \\ P O Box 200, Te Puke, New Zealand
}

\begin{abstract}
"The organic industry is on the tip of the biggest iceberg ever to come our way". These are the recent words of New Zealand's Trade Commissioner in Japan for the last 15 years, Eugene Bowen. He was referring to the rapidly growing trend towards organically grown food in all markets, and particularly in the affluent markets in the Northern Hemisphere.

I have been a kiwifruit grower for twenty years in Te Puke, Bay of Plenty. Five years ago, I began the transition to organic production and now all my fruit is fully certified organic under the "Biogro" label. I am the representative for organic growers to New Zealand Kiwifruit Growers Incorporated and I represent organic producers on the Organic Produce Exporters Group, run by Tradenz.

Last year I travelled as part of a trade mission to all of our major markets. The key driver of demand for organic produce was different in each market. In Europe, the trend to organic food is driven by consumer concerns for the environment. In Belgium, lettuce production will cease in two years on large areas of land which have been judged too polluted for food production. Consumers are aware that their surroundings are heavily laden with toxic residues and are seeking food which has been produced in a non polluting management system.

In the USA, the growth in the organic markets is driven by consumer desire to be healthy and to stay young and fit. Most of the retail stores selling organic produce also have much larger sections devoted to vitamin and mineral supplements. The largest player in the natural foods industry in the USA is a company called "Wholefoods Markets". They now have 78 supermarkets nationwide and one of their primary sales strategies is to provide organic food as part of their natural food product range.

In Japan, the industry is driven largely by concerns for food safety. Increasing cancer rates in Japan have coincided with more 'western' type food. This, combined with a major health scare after an E. coli. outbreak in 1995 has rekindled the Japanese interest in safer food. Japanese have always been fanatical about food quality, especially freshness. This, combined with these new concerns, has driven demand up such that supermarkets are left with insufficient supplies of organic food.

In these three major markets the motivations are slightly different but the trend is the same. Consumption in USA is rising at the rate of 20 percent per year and has done so for the last five years. It is now at US\$3 billion per annum. Germany has the highest consumption of organic products, at $3.5 \%$ of total food consumption. In Europe, USA and Japan, a $20 \%$ price premium over conventional product is now a well-accepted standard. The largest supermarket chain in France, Carrefour, has announced that it plans to increase shelf space for organics in all its stores. The effect of this will be to make organic food accessible where people normally shop, instead of being limited to specialty stores.

There is currently a shortfall in supply in nearly all organic products. In Denmark, the supply of organic dairy products is run out by day three of every week. Growth in demand will depend on the availability of competitively-priced organic produce in the stores. It is the failure to break this vicious cycle which has reduced the opportunities for organics.

The value of organic production in New Zealand reached \$20 million in 1997 (Tradenz OPEG Exporting Survey 1997). This is $30 \%$ of the total value of New
\end{abstract}

Proc. 50th N.Z. Plant Protection Conf. 1997: 11-13 
Zealand's export wine industry and has doubled from $\$ 10$ million in 1996. It is made up of kiwifruit and other fresh produce, frozen vegetables, meat, wool, ice-cream and yoghurt, honey, jams and pickles. The main markets for New Zealand are Europe, Scandinavia and Japan.

TABLE 1: Value of organic exports by market (\$NZ)(Tradenz OPEG Exporting Survey 1997).

\begin{tabular}{lrl}
\hline \multicolumn{1}{r}{ Country } & 1997 & 1996 \\
\hline Japan & $15.75 \mathrm{~m}$ & $5.28 \mathrm{~m}$ \\
Europe & $2.1 \mathrm{~m}$ & $2.56 \mathrm{~m}$ \\
USA & $1.5 \mathrm{~m}$ & $1.63 \mathrm{~m}$ \\
Australia & $0.89 \mathrm{~m}$ & $0.62 \mathrm{~m}$ \\
Other & $0.08 \mathrm{~m}$ & $0.02 \mathrm{~m}$
\end{tabular}

Total value 1997 \$NZ 20,241,335

The organic sector is in the early years of commercialism. Ten years ago all organic growers were typified by their long hair, beards and Roman sandals. Most holdings were very small and they were making only a subsistence living. The last five years has seen the emergence of large commercial organic producers who produce volumes large enough to export. Some examples are :"Biofarm" of Palmerston North exporting dairy products; "Waitaki Apiaries" of Canterbury exporting organic honey to Scandinavia; "Only Organic" of Christchurch exporting organic baby food; "Heinz Wattie" exporting frozen foods; and, of course, Zespri International exporting kiwifruit.

Now, the organic industry is expanding with the conversion of successful commercial farms, gardens and orchards. The next five years will see the organic sector's coming of age with the introduction of government regulations controlling the certification and labelling of organic products and a unified national body promoting New Zealand as a high integrity organic producer.

The rate of conversion to organic production is slow at present. Many factors need to come together for conventional producers to convert to organics. There is a clearlydefined demand pull for organic product with the dollar premiums of $20 \%$ in the market place being reflected back to kiwifruit producers as a $60 \%$ premium.

The question most often asked is "Can yield and quality be sustained?". A 1996 survey of the kiwifruit industry has shown that yields in organic cropping are $30 \%$ below yields from conventional production systems (Fairweather 1996).

Perceptions of the culture of the organic industry are also a barrier. Many conventional growers feel the industry is radical, perhaps left wing and that they would not fit in or would not want to fit in.

In kiwifruit, the ability to produce a market acceptable product has been powerfully aided by the research and new technology produced by Hort Research. The knowledge they have contributed has provided the basis for pest monitoring, and for control of pests using non-toxic sprays. This has not only provided the necessary technology but has increased the credibility of organic husbandry and made producers more confident of making the conversion to organics.

Other crops are still facing the barrier of pest and disease control in order to meet export quarantine criteria. New Zealand's research fraternity has a vital role to play in enabling New Zealand producers to take the opportunity of supplying the rapidly growing and lucrative market for organic food.

Keywords: organic production, trade, markets, industry

\section{ACKNOWLEDGEMENTS}

Funding for the Trade Mission was provided by jointly by Tradenz and the New Zealand Kiwifruit Marketing Board. 


\section{REFERENCES}

Bennett-Smith, J., 1997. Exporting Survey. Organic Producers Exporting Group. Tradenz, Wellington.

Fairweather, J., 1996. The decision making of kiwifruit growers as indicated by attitudes to the Kiwigreen programme, November. Report to New Zealand Kiwfruit Marketing Board by Agribusiness and Economics Research Unit, Lincoln University, Canterbury, New Zealand. 